\title{
A STUDY ON DIGITAL CITIZENSHIP: PRESCHOOL TEACHER CANDIDATES VS. COMPUTER EDUCATION AND INSTRUCTIONAL TECHNOLOGY TEACHER CANDIDATES
}

\author{
Dr. Filiz ELMALI \\ ORCID: 0000-0002-5060-7383 \\ Faculty of Education, Firat University \\ Elazig, TURKEY \\ Dr. Ahmet TEKIN \\ ORCID: 0000-0001-9261-8243 \\ Faculty of Education, Firat University \\ Elazig, TURKEY \\ Ebru POLAT \\ ORCID: 0000-0002-2546-7040 \\ Elazig Science and Art Center, MEB \\ Elazig, TURKEY
}

Received: 24/09/2019 Accepted: 10/02/2020

\begin{abstract}
The main goal of this study is to determine the digital citizenship perceptions and digital citizenship levels of preschool teacher candidates in terms of digital rights and responsibilities, digital security and digital law by comparing them with Computer and Instructional Technologies teacher candidates' perception. To this end, we worked with 80 teacher candidates in total. Both qualitative and quantitative research methods were employed. To identify participants' digital citizenship levels, a questionnaire was administered. Also, semi-structured interviews were conducted to understand their digital citizenship perceptions. The results showed that participants' digital citizenship levels were above average and their digital citizenship perceptions supported this result. In addition, their responses related to digital security, digital rights and responsibilities, and digital law were parallel to their definitions in the literature and they connected them with digital communication and ethics. However, teacher candidates' misconceptions in terms of digital rights and responsibilities and digital security were observed.
\end{abstract}

Keywords: Teacher candidates, technology, digital citizenship, digital citizenship perceptions.

\section{INTRODUCTION}

Developments in today's technologies have changed the meaning of citizenship and introduced the concept of digital citizenship. Although digital citizenship was initially described as online access, it has recently been re-defined as using digital technologies in a safe and responsible manner, or in other words, behavioral norms in digital environments (Ribble, Bailey \& Ross, 2004, Jones \& Mitchell, 2016; Yue, Nekmat \& Beta, 2019). Cubukcu and Bayzan (2013) defined digital citizenship as people using technological tools in an accurate, reliable and accountable manner, and they defined a digital citizen as a person who respects ethical rules and individual rights in digital environments. A good digital citizen, however, should be able to interfere with inappropriate behavior and help other people to use technology effectively (Ribble, 2011). Digital access, digital commerce, digital communication, digital literacy, digital security, digital health, digital rights and responsibilities, digital law and constitute the elements of digital citizenship (Hill, 2015). Among them, this study digital ethics examines three main elements of digital citizenship: digital security, 
digital rights and responsibilities, and digital law. The rationale of this choice is that in the literature, studies found that although teacher candidates have sufficient knowledge in digital access, digital commerce, digital communication, digital literacy, digital health, and digital ethics, they have insufficient knowledge in digital security, digital rights and responsibilities, and digital law (Hollandsworth, Donovan, \& Welch, 2017; Jones and Mitchell, 2016; Sincar, 2011).

\section{DIGITAL CITIZENSHIP TODAY}

Recent developments in digital technologies have restructured the way people live and communicate (Aslan, 2016; Ohme, 2018; Siemens, 2005; Schlichter \& Danylchenko, 2014). Weigel, James and Gardner (2009) emphasize that individuals meet digital technology at a very early age and spend a long time with digital technologies during critical developmental stages. In an information society, people are expected to show active attitudes and participation in matters such as digital decision making, ethics and legal issues, and online security (Hollandsworth, Dowdy, \& Donovan, 2011). Developments in digital technologies, the requirements of information society, increased number of communication ways, and unlimited access to information brought forth the concept of digital citizenship (Aslan, 2016). Digital citizens, full members of an online community, are individuals who make frequent use of technology, benefit from digital technologies while performing their citizenship duties, and use technology for economic purposes (Mossberger, Tolbert $\&$ McNeal, 2008). They are also those who have the ability to access, use, create, evaluate information, and communicate with others in online environments (Choi, 2016). Jones and Mitchell (2016) distinguished digital citizenship from the prevention of cyberbullying or only digital literacy, and defined it as using internet resources to perform civic engagement activities with respect and tolerance to others. Along with the changing structure of the society, digital citizens with digital skills and ability to adapt to the society are needed. In regard to the scope of the current study, three sub-dimensions of digital citizenship were explained in the following section.

\section{Digital Security}

Due to the widespread use of digital media and the development of internet technologies, access to information is easier than ever and behaviors of sharing information increase day by day (Liu, Safavi-Naini \& Sheppard, 2003; Xu, Yang, MacLeod \& Zhu, 2019). Despite the positive effects of the intensive use of digital media, digital security problems also arise (Yilmaz, Sahin and Akbulut, 2015). There are risks in digital environments such as viruses, cyber-attacks, digital rights violations, online theft, fraud, cyber bullying and child abuse (Kim, Jeong, Kim, \& So, 2011). For example, Livingstone, Haddon, Gorzig and Ólafsson (2011) investigated security issues and risks on the internet in a study with children aged 9-16 in 25 European countries and found out that children were exposed to messages and photos with sexual content and bullying. This means that individuals start encountering problems in digital environments at an early age. Individuals need to be aware of digital security and take the necessary precautions to protect themselves from these risks. The literature contains studies on digital security awareness of individuals. In their study, Pusey and Sadera (2011) investigated digital security knowledge levels of prospective teachers. They found that prospective teachers had limited knowledge of digital security, and they had limited or no knowledge of $60 \%$ of the information presented in the questionnaire that included cybercrime- and cyber-security-related items. Additionally, prospective teachers emphasized that they could only teach $4 \%$ of information about cyber ethics and cyber security to their students (Pusey \& Sadera, 2011). In similar studies, the digital security awareness levels of teachers were low (Akgun \& Topal, 2015; Turkey, Gokmen \& Akgun, 2015). Table 1 summarizes the behaviors that are expected from users in terms of digital security. 
Table 1. Expected behaviors related to digital security

\begin{tabular}{ll}
\hline Expected Behaviors & Sources \\
\hline Not sharing personal information with strangers & Ivanoff and Belvery (2016) \\
Checking privacy settings on social media & Ribble (2011) \\
Not sharing information in online settings & Ribble (2012) \\
Protecting personal information & Ribble (2011) \\
Taking necessary actions for personal security & Kaya and Kaya (2014) \\
Being aware of unsafe files that might threaten computers & Sakalli (2015) \\
Taking electronic precautions in digital environments & Isman and Canan Gungoren (2013) \\
Creating strong passwords & Ivanoff and Belvery (2016) \\
Using anti-virus programs & Ribble (2011); Isman and Canan \\
Using firewall & Gungoren (2013) \\
Protecting hardware and software & Ribble (2011) \\
\hline
\end{tabular}

\section{Digital Rights and Responsibilities}

Digital citizenship includes online activities related to health, education, public services and so on (Mossberger, Tolbert \& Anderson, 2014). All individuals in a society have the right to benefit from these services and use digital technologies (Kocadag, 2012). Digital rights and responsibilities, one of the fundamental elements of digital citizenship, draw attention to this issue. Digital rights and responsibilities are defined as using digital technologies freely, while having awareness of the responsibilities in behaviors in digital environments and acting accordingly (Al-Zahrani, 2015; Greenhow \& Robelia, 2009; Kaya \& Kaya, 2014) and warning or complaining about those who abuse digital environments (Ribble, \& Miller, 2013). Third, Bellerose, Dawkins, Keltie and Pihl (2014) organized workshops with 148 children in 16 countries to determine the participants' views on children's rights in the digital age. They found that children were increasingly seeing digital technology as a fundamental right, they thought of digital rights and human rights as a singular concept, and they were aware of their responsibilities in digital environments. Additionally, in the study, children expressed the importance of digital technology for accessing information, education, and societal engagement (Third, Bellerose, Dawkins, Keltie \& Pihl, 2014). In Turkey, there are studies conducted with older individuals rather than younger age groups. In his study, Bakir (2016) concluded that prospective teachers had partial knowledge in defining their digital rights and responsibilities; however, they did not feel free enough in digital environments. In another study, Aslan (2016) concluded that prospective teachers were aware of their digital rights and responsibilities, but sometimes they did not comply with copyrights. Table 2 refers to behaviors that are expected in relation to digital rights and responsibilities in the literature. 
Table 2. Expected behaviors related to digital rights and responsibilities

\begin{tabular}{ll}
\hline Behaviors & Source \\
\hline Being aware of privacy rights & Tan (2011) \\
Reporting inappropriate behaviors in digital environment & Ribble (2011); Sakalli, (2015) \\
Being free in digital environment & Ribble (2011); Isman and Canan Gungoren (2013) \\
Free use of digital technologies & Cubukcu and Bayzan (2013); Sakalli (2015) \\
Using technology properly & Tan (2011) \\
Being aware of responsibilities while using technology & Tan (2011) \\
Using online materials after getting permissions & Ribble (2011) \\
$\begin{array}{l}\text { Being aware of equality in the rights of all users in the digital } \\
\text { environment }\end{array}$ & Ribble (2011) \\
Expressing oneself freely in digital environment & Sakalli (2015) \\
Understanding rules in the digital environment & Ribble (2011) \\
Helping others in the digital environment & Ribble (2011) \\
\hline
\end{tabular}

\section{Digital Law}

Digital citizenship is not just the awareness of the risks that can be encountered in digital environments and being protected against these risks. Digital citizens are expected to use digital technologies in a responsible manner (Karaduman and Ozturk, 2014). This situation creates the concept of digital law, which is defined as the awareness of the responsibilities in behaviors and actions in digital environments (Ribble, 2011). Digital citizens are expected to be aware of the rules, laws, and policies that are effective in digital environments and comply with these rules, laws and policies (Cubukcu \& Bayzan, 2013). Furthermore, individuals should be able to see the link between real and virtual life and be aware that basic laws also apply in virtual life (Ribble, \& Miller, 2013). In their study, Agamba and Keengwe (2012) investigated prospective teachers for taking precautions against crimes committed in the digital environment. Based on their findings, they reported that prospective teachers' level of awareness against digital crime was low. In another study, York (2014) investigated prospective teachers' knowledge of digital law and found that prospective teachers had partially correct perceptions about digital law, but they had a lack of knowledge. As a result of the study, it was emphasized that prospective teachers should be given extensive training in issues of digital law (York, 2014). In the studies conducted in Turkey, while Zeybek (2011) found that high school students did not pay enough attention to intellectual property rights, Gokmen and Akgun (2015) emphasized that prospective teachers did not know about the laws and articles related to cybercrimes in the legal system. In another study, Gokmen and Akgun (2016) stated that prospective teachers did not know what to do when they encountered cybercrime. According to these results, it is evident that prospective teachers' levels of knowledge on digital law are not sufficient. Table 3 shows the behaviors that are expected in relation to digital law based on the literature.

Table 3. Expected behaviors related to digital law

\begin{tabular}{ll}
\hline Behaviors & References \\
\hline Being aware of laws related to use of digital technologies & Ribble (2012) \\
Being aware of criminal sanctions as a result of inappropriate use of digital technology & Sakalli (2015) \\
Abiding by the rules of the digital environment and warning those who do not & Sakalli (2015) \\
Knowing that things that are crimes in real life are also crimes in the digital environment & Sakalli (2015) \\
Being aware of the copyright laws in digital environments & Ribble (2011)
\end{tabular}


Digital citizenship is a way of preparing individuals for a society filled with technology (Ribble, 2011). Digital technologies have a strong influence on the lives of individuals, and there has been a significant increase in the use of technology among young people in recent years (Rideout, Foehr, \& Roberts, 2011). In this context, the aim of the research is to determine the digital citizenship perceptions and digital citizenship levels of preschool teacher candidates and compare them to prospective Computer Education and Instructional Technologies (CEIT) teachers who receive training in the field of technology. The effects of technology on society show that there will be many changes in the coming decade and children are at the center of these changes (Park, 2016). Children are growing in a constantly digitized environment (Sullivan \& Bers, 2016). The use of technology by children ranges from watching television to playing video games, reading electronic books, listening to music, using computers/tablets and so on (Ernest et al., 2014). Based on his study, Palaiologou (2016) encourages children to use digital technology and suggests that school environments should allow and enable the active use of digital technologies to balance the use of digital technology at home. Preschool teacher candidates have various responsibilities as a result of technology being used in early ages due to IT devices' positive effects on the learning of young children, positive transformation of the use of digital technology at home, and recognition of the role of technology (McCarrick \& Li, 2007; Parette, Quesenberry \& Blum, 2010; Hatzigianni, \& Margetts, 2012; McManis \& Gunnewig, 2012; Nikolopoulou, 2014; Palaiologou, 2016; Janisse et al., 2017). In addition, Blackwell and colleagues concluded that most of the studies were carried out on K-12 teachers and these were mainly focused on barriers that prevent teachers using technology in their classrooms (Blackwell et al., 2013). Since there are not enough studies on teacher candidates in the literature, it is important to investigate digital citizenship levels of preschool teacher (PT) candidates in this context. On the other hand, Computer Education and Instructional Technologies teacher (CEIT) candidates receive intensive training on information technologies; therefore, they were considered as a benchmark in determining the digital citizenship perceptions and levels of preschool teacher candidates within the scope of this study. This study focuses on senior students, considering that they have already taken the Teaching Practice and School Experience courses, they are about to complete their education, and are about to start their professional careers. Answers to the following questions were sought:

1. What are the main purposes of technology use among PT and CEIT candidates?

2. What are the digital citizenship levels of PT and CEIT candidates?

3. What are the PT and CEIT candidates' perceptions related to digital citizenship?

4. What are the PT and CEIT candidates' perceptions about rights and responsibilities?

5. What are the PT and CEIT candidates' perceptions about digital security?

6. What are the PT and CEIT candidates' perceptions about digital law?

\section{METHOD}

\section{Research Model}

In this study, a quantitative research method was used to determine the digital citizenship levels of teacher candidates, and a qualitative research method was used to determine digital citizenship perceptions. While the quantitative research approach is about measurement, the qualitative approach is about unearthing (Buyukozturk et. al., 2012). Indeed, the use of qualitative methodology allowed participants to express their perceptions about digital citizenship. It also allowed us to identify misconceptions concerning digital citizenship. The findings are supported with some quotations from the interviews.

\section{Study Group}

Quantitative data were collected from 80 teacher candidates studying at a university in the eastern region of Turkey and selected by the method of convenience sampling method. There were 92 undergraduate students registered to both major and they were informed about the study. Among them, 80 teacher candidates (37 CEIT Candidates and 43 PT Candidates) agreed to participate. Qualitative data of the study were obtained from a total of 34 candidate teachers 17 CEIT and 17 PT candidates, who were randomly selected from 80 teacher candidates. The identities of the participants were concealed by giving them code names ranging from PT-1 to PT-17 and CEIT-1 to CEIT-17. Table 4 shows teacher candidates demographic information. 


\section{Data Collection Tools}

A five-point Likert-type scale entitled the Digital Citizenship Scale that was developed by Isman and Canan Gungoren (2014) was used to determine the digital citizenship levels of the teacher candidates. The scale consists of nine sub-dimensions including digital literacy, digital law, digital rights and responsibilities, digital communication, digital security, digital commerce, digital access, digital ethics and digital health. The Cronbach Alpha internal consistency coefficient of the scale was .85. According to Isman and Canan Gungoren (2014), the highest and lowest scores are 165 and 33, with the average score of 99. This study focuses only on the sub-dimensions of rights and responsibilities, security and legal aspects of digital citizenship, and all the analyses were carried out on these three dimensions.

In order to determine the digital citizenship perceptions of teacher candidates, a semi-structured interview form that was developed by the researchers was used. The interview form was examined in terms of content validity by three experts (a faculty member in the Department of CEIT, a faculty member in the Department of Early Childhood Education, and an Information Technologies teacher in the Ministry of National Education). The interview questions were assessed by two Turkish language teachers in terms of Turkish congruence. Additionally, the interview questions were asked to five CEIT and five PT candidates outside the study group and the comprehensibility of the questions was tested. Unclear or incomprehensible questions were excluded from the interview form based on expert opinions. Based on these evaluations, the interview questions were reduced from ten to five.

\section{Data Analysis}

In this study, descriptive analysis was used to determine the existing situation. Content analysis technique was used to analyze the data gathered from the interviews. Reliability for the interviews was calculated by percent agreement [agreement / (agreement + disagreement)]. The reliability was 92\%. The researchers discussed codes/sub-codes on which the researchers disagreed and carried out coding based on consensus to create the final data. The quantitative data were analyzed by a data analysis program. Frequency, percentage, and mean scores were used for the analysis.

\section{FINDINGS}

First, the respondents were asked about the purpose of their internet use. The findings about the purpose of internet use by the teacher candidates are shown in Table 4. Among the purposes, it was quite clear that there is far greater use of the internet for communication, social media site visits and listening to music for PT candidates. Similar results were found for CEIT candidates, except for listening to music. Instead, they reported use of internet for reading news. 
Table 4. Teacher Candidates' Use of Internet

\begin{tabular}{lllll}
\hline & \multicolumn{2}{c}{ PT Candidates } & \multicolumn{2}{c}{ CEIT Candidates } \\
Use of Internet & $\mathrm{n}$ & $\%$ & $\mathrm{n}$ & $\%$ \\
\hline Chatting/messaging & 30 & 83.3 & 31 & 72.1 \\
Online games & 15 & 41.7 & 8 & 18.6 \\
Listening to music & 31 & 86.1 & 15 & 34.9 \\
Reading newspaper/watching news/obtaining & 28 & 77.8 & 27 & 62.8 \\
information & 23 & 63.9 & 11 & 25.6 \\
Official matters/ Online banking & 24 & 66.7 & 14 & 32.6 \\
Shopping & 32 & 88.9 & 24 & 55.8 \\
Social Network Site visits & 10 & 27.02 & 5 & 11.62 \\
Researching & 6 & 16.21 & - & \\
Following online courses & 3 & 8.10 & 2 & 4.65 \\
Watching movies, series or documentaries & - & & 3 & 6.97 \\
Stalking & 11 & 30.6 & 2 & 4.65 \\
Others & & &
\end{tabular}

\section{Digital Citizenship Levels of Teacher Candidates}

Findings related to 'Digital Citizenship Scale' are presented in Table 5.

Table 5. Teacher candidates' digital citizenship levels

\begin{tabular}{lcccccc}
\hline & \multicolumn{3}{c}{ PT candidates $\overline{\mathrm{X}}$} & \multicolumn{3}{c}{ CEIT candidates $\overline{\mathrm{X}}$} \\
& $\mathrm{n}$ & & ss & $\mathrm{n}$ & & ss \\
\hline Digital Citizenship levels & 43 & 119.16 & 15.53 & 37 & 124.70 & 10.10 \\
Digital Law sub-factor & 43 & 15.37 & 2.08 & 37 & 15.37 & 2.34 \\
Digital Rights and Responsibilities sub-factor & 43 & 17.02 & 2.12 & 37 & 16.32 & 2.13 \\
& & & & & & \\
Digital Security sub-factor & 43 & 9.97 & 1.92 & 37 & 9.64 & 2.32 \\
\hline
\end{tabular}

According to the results of the analysis, the mean score of the digital citizenship levels of CEIT teacher candidates was 124.70, and that of pre-school teachers was 119.16 .

Based on these findings, it may be stated that the digital citizenship levels of CEIT and PT candidates were above average.

\section{Teacher Candidates' Perceptions of Digital Citizenship}

Teacher candidates participating in the study were asked to define the concept of digital citizenship to determine their perception on digital citizenship. PT candidates emphasized the importance of using technology positively and critically while defining the concept of digital citizenship, whereas CEIT teacher candidates emphasized the effective use of technology. The findings obtained in this study were examined in three main categories: "Technology literacy", "Technology, Morality and Ethics" and "Rights and responsibilities in technology use". Table 6 shows teacher candidates perceptions related to digital citizenship. 
Table 6. Teacher candidates perceptions related to digital citizenship

\begin{tabular}{|c|c|c|}
\hline Themes & $\begin{array}{l}\text { PT candidates } \\
\mathrm{f}\end{array}$ & $\begin{array}{l}\text { CEIT candidates } \\
\mathrm{f}\end{array}$ \\
\hline \multicolumn{3}{|l|}{ Technology literacy } \\
\hline Using technology effectively & 4 & 8 \\
\hline Using technology as a communication tool & 2 & - \\
\hline Completing civic duties through technology & 1 & 1 \\
\hline Being aware of the agenda & 1 & - \\
\hline Using technology securely & - & 4 \\
\hline Access to the information through technology & - & 3 \\
\hline \multicolumn{3}{|c|}{ Technology, Morality and Ethics } \\
\hline Using technology in a positive way & 15 & 5 \\
\hline Encouraging good and moral things & 5 & - \\
\hline Using technology on behalf of society & 2 & 2 \\
\hline Using technology responsibly & - & 4 \\
\hline \multicolumn{3}{|c|}{ Rights and responsibilities in technology use } \\
\hline Acting/thinking critically while using technology & 8 & 2 \\
\hline Knowing rights and responsibilities & 3 & 2 \\
\hline Knowing the consequences of behavior in online environment & 3 & - \\
\hline
\end{tabular}

Examples of the statements are given below:

"It is the correct and proper use of technology by citizens and promoting ethical behaviors while using technology. A digital citizen is someone who uses information and communication tools in digital environments within ethical boundaries, who encourages and guides those who abuse digital tools to use these tools within ethical boundaries, and supports ethical behaviors". [PT-3, encouraging good and moral things; using technology effectively]

"Being one with technology. Using technology in your life. Fulfilling citizenship duties through technology." [PT-11, using technology on behalf of society]

"It is the procedures related to the state, and the confidentiality, ethical rules and behaviors regarding the use of technology." [CEIT-6, completing civic duties through technology]

"Digital citizens should have the ability to use the Internet and digital media, question the accuracy of the information they are searching for, and be aware of their rights and responsibilities in digital environments." [CEIT-5, using technology effectively; knowing rights and responsibilities; acting/thinking critically while using technology]

\section{Perceptions about Rights and Responsibilities}

In order to determine the opinions of candidate teachers about digital rights and responsibilities, which is a sub dimension of digital citizenship, candidate teachers were asked: "What rights and responsibilities do you think you have in digital environments?" The views of candidate teachers on this subject are given in the Table 7. 
Table 7. Teacher candidates' perceptions about rights and responsibilities

\begin{tabular}{lcc}
\hline & PT candidates & CEIT candidates \\
Themes & $f$ & 10 \\
\hline Security and privacy & 7 & 1 \\
Complaining about disturbing people/behaviors & 11 & 4 \\
Freedom of opinions and thoughts & 6 & 2 \\
Information acquisition and dissemination & 4 & - \\
Internet access right & 1 & - \\
Pay attention when sharing & 8 & - \\
Responsibility to use proper names & 5 & - \\
Using trusted sites and getting membership & 2 & - \\
Responsibility for respecting ideas & 3 & - \\
Responsibility to use technology in a moral and ethical way & 2 & 1 \\
Distinguishing good and bad rights & 1 & - \\
Having rights and responsibilities in real life and online & 1 & - \\
environment & & 6 \\
Participating in useful and appropriate activities & 1 & 3 \\
Spending time efficiently & 1 & 2 \\
Having right to privacy & - & 2 \\
Right of intellectual property & - & 1 \\
Originality & - & 1 \\
Right to social interaction & - & \\
Right to use rights and responsibilities & - & - \\
Equal opportunity & - & - \\
\hline
\end{tabular}

Some statements provided by the candidates are given below.

"I report the content, pictures, text or videos that I see are harmful or disturb me." [PT-6, complaining about disturbing people/behaviors]

"I report inappropriate websites and people that disturb me." [PT-7, complaining about disturbing people/ behaviors]

"Privacy rules, personal information, copyright and privacy rights." [CEIT-15, security and privacy]

"I think that in a digital environment, I have the right and responsibility to protect privacy, not to use people's information on any platform, and to enforce justice for those who attack my rights." [CEIT-1, security and privacy]

\section{Perceptions about Digital Security}

Teacher candidates' views were determined about digital security, which is another sub-dimension of digital citizenship. The findings were examined based on the subcategories of "personal precautions" and "technological precautions". 
Table 8. Teacher candidates' perceptions about digital security

\begin{tabular}{lcc}
\hline & PT Candidates & CEIT candidates \\
Themes & $f$ & $f$ \\
\hline Personal precautions & 9 & 3 \\
\hline Not to communicate with strangers & 8 & 5 \\
Paying attention while posting & 7 & 5 \\
Not to share personal information & 13 & 12 \\
Using trusted and age appropriate websites & 2 & - \\
Complaining on disturbing behaviors & 1 & - \\
Logging in with security code & 1 & - \\
Using proper names (not using fake names) & 1 & - \\
Not to fool anyone with lies & 1 & 1 \\
Not to download unsafe files/applications & 1 & 2 \\
Not to insult others & 1 & 1 \\
Paying attention to the posts of the websites & - & 3 \\
Avoiding viruses & - & 8 \\
Creating difficult-to-crack passwords and security questions & - & 3 \\
Avoiding cyber-crimes & & 7 \\
\hline Technological Precautions & 6 & - \\
\hline Setting up privacy settings & 1 & - \\
Using antivirus software & & \\
Activating the firewall & & \\
\hline
\end{tabular}

It is seen in Table 8 that preschool teacher candidates mostly emphasized individual measures such as not communicating with strangers (9), adjusting privacy settings (7), being careful when posting on social media (8) and not sharing personal information (7). The views of preschool candidate teachers on this subject were as follows:

"I do not let strangers follow me on social media." (PT-11, not to communicate with strangers),

"I try to be careful whenever I share an image, video, etc. on social media. I adjust my privacy settings, so strangers do not see me. I do not friend everyone online." (PT -3, paying attention while posting),

"I always activate security software (antivirus, deepfreeze, firewall etc.). I never share my personal information. Generally I use e-government applications." (CEIT-2, using antivirus software, activating the firewall, not to share personal information, using trusted and age appropriate sites)

"I use antivirus and firewall software. I make my passwords from various numbers and letters. I do not click on random links." (CEIT-3, using antivirus software, activating the firewall, using trusted and age appropriate sites)

\section{Perceptions of Digital Law}

Candidate teachers were asked the questions "Do you think behaviors in digital environments have legal consequences? What kind of legal consequences do you think can be encountered?" to assess their views on another sub-dimension of digital citizenship: digital law. Table 9 shows teacher candidates perceptions about digital law. 
Table 9. Teacher candidates perceptions about digital law

\begin{tabular}{lcc}
\hline & PT Candidates & CEIT candidates \\
Themes & $\mathrm{f}$ & $\mathrm{f}$ \\
\hline Legal Penalties & 3 & 6 \\
Imprisonment & 3 & 6 \\
Fine & 1 & - \\
Being fired from job & 1 & - \\
Banned from social media accounts & & - \\
Social Penalties & 1 & \\
Social disapproval & 1 & \\
\hline
\end{tabular}

The views of candidate teachers on this subject were as follows:

"Just as there is a criminal liability for every crime, there are penal and judicial responsibilities for misconduct in a digital environment. These penalties may be monetary or even prison sentences." [PT-5, legal penalties, imprisonment]

"I may face legal consequences if I insult legal or real persons, such as the closure of social media accounts, fines, etc." [PT-11, legal penalties, banned from social media accounts]

"It's a sanction because of fake accounts. There are legal consequences of issues resulting from online payment systems in shopping sites. In such cases, imprisonment based on certain behaviors or monetary penalty can be applied." [CEIT-6, legal penalties, imprisonment]

"I know that there is a cybercrimes unit, and there are prison sentences against hate crimes, cyber-attacks, and hacks on computer systems that are made online." [CEIT-8, imprisonment]

\section{Misconceptions}

During the analysis process, teacher candidates' misconceptions were observed. Table 10 was organized to provide themes, under which element the participants considered them, and under which element they were needed to be considered based on the literature. To this end, Ribble and Bailey (2005), Tan (2011), Sakalli (2015), Ribble (2011), Ribble (2012), Isman and Canan Gungoren (2013), Gormez (2016) were taken into account. One critical thing in Table 11 is that PT candidates mainly have misconceptions about digital citizenship, comparing with CEIT candidates. For instance, although PT-3 considered "having the right to access to the internet" as digital rights, it must be considered for digital access. Another example is that although CEIT 6 explained his concerns about shopping sites (images in a commercial site, its followers, payment options) under the digital security, it must be considered under the digital commerce based on the literature. 
Table 10. Teacher candidates' misconceptions

\begin{tabular}{|c|c|c|c|}
\hline Theme & $\begin{array}{c}\text { PT candidates } \\
\mathrm{f}\end{array}$ & $\begin{array}{c}\text { CEIT candidates } \\
\mathrm{f}\end{array}$ & $\begin{array}{l}\text { Elements in which } \\
\text { the themes belonged } \\
\text { to based on the } \\
\text { literature }\end{array}$ \\
\hline \multicolumn{4}{|l|}{ Digital rights and responsibilities } \\
\hline Disseminate and acquire information & 4 & 2 & Digital access \\
\hline Internet access right & 1 & - & Digital access \\
\hline Attention while sharing information & 8 & - & Digital security \\
\hline $\begin{array}{l}\text { Responsibility to benefit from technology in a } \\
\text { moral and ethical way }\end{array}$ & 2 & - & Digital ethics \\
\hline Effective use of time in online environment & 1 & - & Digital health \\
\hline Social interaction right & - & 2 & $\begin{array}{l}\text { Digital } \\
\text { communication }\end{array}$ \\
\hline Shopping at secured websites & 4 & 1 & Digital commerce \\
\hline Complaining about disturbing behaviors & 2 & - & $\begin{array}{l}\text { Digital rights and } \\
\text { responsibilities }\end{array}$ \\
\hline \multicolumn{4}{|l|}{ Digital security } \\
\hline Not to fool anyone with lies & 1 & - & $\begin{array}{l}\text { Digital rights and } \\
\text { responsibilities }\end{array}$ \\
\hline No insulting & 1 & - & $\begin{array}{l}\text { Digital rights and } \\
\text { responsibilities }\end{array}$ \\
\hline Acting in online environment like in real life & 1 & 3 & Digital ethics \\
\hline
\end{tabular}

\section{RESULTS AND DISCUSSION}

Developments in digital technologies have created a new definition of citizenship with transformed social, cultural and individual characteristics (Hermes, 2006; Isman \& Canan Gungoren, 2013; Choi, Glassman \& Cristol, 2017). Efforts of supporting students in a digital society and instill certain behavioral norms, in other words, increasing their awareness to become digital citizens requires training and role models (Hollandsworth, Dowdy \& Donovan, 2011). Accordingly, it has become a necessity to examine the digital citizenship perceptions and levels of teacher candidates who will train the future generations.

In this study, digital citizenship perceptions and levels of preschool and CEIT teacher candidates were examined in terms of digital rights and responsibilities, digital security and digital law. Based on the results of the study, it was seen that the digital citizenship levels of the teacher candidates was above average, and their digital citizenship perceptions supported this result. Educational institutions need to develop common policies, standards, and language to enable ethical and moral use of technology and display positive behaviors (Hollandsworth, Dowdy \& Donovan, 2011). In this context, it is clear that a greater emphasis is needed on the appropriate use of technology in Preschool Teacher preparation programs (Parette, Quesenberry \& Blum, 2010).

When the literature is examined, it is seen that studies reported an above average digital citizenship level among teacher candidates (Akcil, Altinay and Altinay, 2016; Alqahtani, Alqahtani and Alqurashi, 2017; AlZahrani, 2015; Kocadag, 2012; Sakalli, 2015; Sakalli and Ciftci, 2016). Similar results were found in this particular study as well. It is gratifying that teacher candidates who will train the digital citizens of today have an above average digital citizenship level. However, such hopeful results were not observed in other studies with similar research goals across other disciplines in teacher education programs (see Beycioglu, 2012; Karaduman, 2017). Thus, more research is needed on this topic.

Students use digital technologies not only outside the school but also at the school (Hollandsworth, Dowdy \& Donovan, 2011). Digital citizenship needs to be included in education to support students in a digital society and accept certain norms of behavior in terms of digital citizenship (Ohler, 2012). In the student standards published by the International Society for Technology in Education (ISTE) in 2014, students are 
expected to use and defend technology in a safe, legal, and responsible way, in other words, become digital citizens. Teachers are responsible for preparing students for the digital society or digital citizenship (Lenhart et al., 2011) and play a key role for students developing and implementing digital citizenship norms (Searson, Hancock, Soheil, \& Shepherd, 2015). As Livingstone, Haddon, Gorzig and Ólafsson (2011) stated, teacher training should be carried out to equip young children with necessary digital media skills so that teachers must be ready to educate students in schools that are the perfect places to teach the concept of digital citizenship and nine key elements of digital citizenship (Moreillon, 2013). However, Karaduman (2017) emphasized that about half of the teacher candidates did not receive enough training on digital citizenship during their university education. In the curriculum of education programs approved by the Turkish Higher Education Institution (YOK), as Information Technologies and Instructional Technologies courses are the only mandatory courses that are related to technology and technology use in education (YOK, 2018).

Indeed, use of digital technologies, security of information systems, and ethical concepts are included in the Information Technologies course (YOK, 2018). Considering the teacher candidates' level of digital citizenship and their perceptions about its elements such content is not enough. In addition to developments and changes in technology, findings of this and similar studies make it necessary to change process of teacher training (Berson \& Balyta, 2004; Bolick et al., 2003; Instefjord \& Munthe, 2016; Karaduman, 2017). For practice, it might be suggested to reconsider the contents of the Computer I and II and Instructional Technologies and Material design courses and include digital citizenship and its nine elements as an indispensable piece of content in these courses.

When teacher candidates' digital citizenship perceptions were examined, their views on the concept of digital citizenship were about technology literacy, technology, morality and ethics and rights and responsibilities in technology use. On the other hand, in other studies teacher candidates defined digital citizenship as performing procedures related to public services on the internet and learning and seeking justice about rights in the digital environment (Kaya \& Kaya, 2014); as e-government applications (Bakir, 2016), and as fulfilling their civic duty on the internet, use of digital devices and social networking sites, appropriate use of technology and a change in the perception of citizenship due to technology (Karaduman, 2017). In addition, there were teacher candidates who had no idea about digital citizenship (Karaduman, 2017). Consequently, by considering teachers' critical role on children, it is recommended that digital citizenship should be among the prioritized subjects of education, and beyond this, digital citizenship should not be considered as a topic that is separate from the curriculum, and it should cover all areas of education (Ribble, 2012; Ribble \& Bailey, 2005). Also, in addition to already exist courses, there needs to be elective courses that include topics including use of technology in education, digital citizenship and sub dimension of digital citizenship, and teacher candidates should be encouraged to take such elective courses. For future research, it might be critical to examine the possible association between technology integration opportunities in teacher education programs and teacher candidates' perception of digital citizenship.

When preschool teacher candidates' views on their rights and responsibilities in digital environments were examined, it was seen that reporting disturbing behaviors, being careful while posting on the internet, and security and confidentiality concepts were emphasized. Aslan (2016) stated that digital rights and responsibilities are perceived as online freedom, user privacy, responsibility while posting, copyrights of digital works and not using illegal sites and programs. In two studies by Karaduman (2017) and Bakir (2016), similar definitions about digital rights and responsibilities were found. Yang and Chen (2010) conducted a study with teachers and teacher candidates, and asked the participants what ethical/social/human problems should be considered when digital technologies are applied to current education. In that study, $70.2 \%$ of the participants emphasized that issues related to ethical use of technology, copyrights, and IP rights were encountered. The opinions expressed by the teachers and teacher candidates were similar to those in this study and other studies in the literature. One critical difference of this study was the identification of the participants' misconceptions about digital rights and responsibilities. Although their misconceptions were still under the scope of digital citizenship, for creating collective culture - effective and successful - (Covell, Howe \& McNeil, 2010; Ribble \& Bailey, 2005) education programs should prepare teacher candidates in and outside of classroom activities so they learn and practice these rights and responsibilities. 
In this study, teacher candidates' perceptions about digital security were evaluated under two factors: personal precautions and technological precautions. In similar studies, teacher candidates' digital security perceptions were mainly about encryption, use of trusted sites, and use of antivirus programs (Aslan, 2016; Bakir, 2016). The findings obtained in this study are consistent with those in the literature. Considering the risks that can be encountered when children are exposed to digital environments, children need to be aware of these risks. For this, the greatest support will come from their teachers (Livingstone, Haddon, Gorzig \& Ólafsson, 2011). The role of educators in this process is to teach the security measures necessary for children using online environments to protect themselves (OECD, 2012; Ohler, 2011). Indeed, educators need to gain this knowledge during their education (Pusey \& Sadera, 2011), so that they can play their role in their own classrooms. Pusey and Sadera (2011) also stressed the need that digital security issues should be discussed regularly in schools. To do this, teachers, counselors, and school administrators should act together, and in addition to the warnings during the lessons and topics that can be explained, various seminars that can be provided to the students should be evaluated. In addition, the literature contains studies suggesting that there are various online environments for teacher candidates to increase their digital security awareness (Yang $\&$ Chen, 2010). However, in addition to what educators can do inside and outside the school, internet safety polices should also be reviewed for safe use of technology (Authors, 2016; O’Neill, 2013). For example, the European Union Safe Internet Program plays an important role in promoting online safety of children among member states (OECD, 2012). Digital gaps based on access, usage and knowledge differences necessitate that policies should be tailored accordingly (Livingstone, Haddon, Gorzig, \& Ólafsson, 2011).

A limited number of the teacher candidates mentioned imprisonment and pecuniary penalties for legal responsibilities in behaviors in digital environments. According to Bakir (2016,) teacher candidates perceived the digital law dimension as laws that provided internet security, but the participants did not have enough knowledge on this subject. York (2014) and Aslan (2016) reported that teacher candidates had knowledge of criminal behavior within the context of digital law, but there were also topics on which teacher candidates lacked information or were misinformed. In this study, the perceptions of teacher candidates about the concept of digital law overlapped with the other findings in the literature. Ribble (2012) emphasized that, in order for students to understand the concept of digital law, the rules of technology should be discussed in schools, and why these rules are necessary should be explained. Teachers who will teach this for students need extensive training on digital law during their pre-service training period (York, 2014).

As in other studies, this study also has limitations. One limitation of the study was the educational programs that participants enrolled in and the number of the participants. Future research may replicate this study with teacher candidates from different fields. Another limitation was that this study only focused on three elements of digital citizenship: digital rights and responsibilities, digital security and digital law. Researchers may focus on the remaining elements in order to understand teacher candidates' digital citizenship perceptions better. Moreover, in the data analysis, correlational data analysis based on the demographic information of the teacher candidates was not performed. It is recommended to investigate how demographic characteristics may affect digital citizenship and its sub-dimensions.

Authors' Note: A brief description of this study was presented at the $\mathrm{X}^{11}$ Computer and Instructional Technology Symposium in Malatya, TURKEY. 


\section{BIODATA and CONTACT ADDRESSES of AUTHORS}

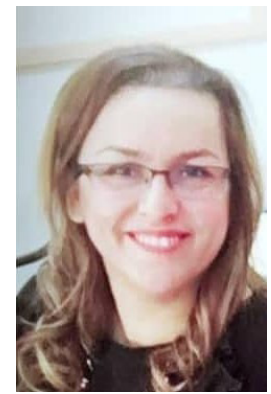

Dr. Filiz ELMALI is an associate professor at Faculty of Education, Firat University. Dr. Elmali gained her Ph.D. in Teaching and Learning at Vanderbilt University, USA, at December 2009. Her academic interest areas are teacher education, social media, technology integration into education, cyberloafing, and e-learning. She has over 18 journal articles published in international indexes. Also, she has other national and international articles and papers submitted to international meetings.

\section{Filiz ELMALI}

Department of Primary Education, Faculty of Education

Address: Firat University, 23119, Elazig, Turkey

Phone: +90 5309130123 ,

E-mail: fvarol@firat.edu.tr

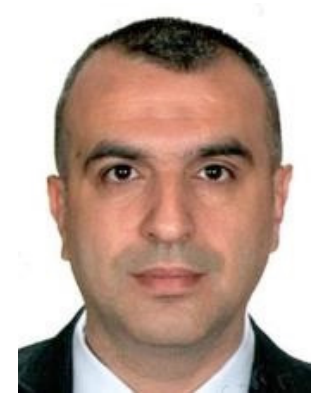

Dr. Ahmet TEKIN received the BSc and MSc degrees in electronics and computer education from Firat University, Elazig, Turkey, in 1996 and 2003 respectively, and the $\mathrm{PhD}$ degree in electrical and electronics engineering from Firat University, Elazig, Turkey, in 2009. He is currently Prof. Dr. in the department of Computer Education and Instructional Technology, Education Faculty, Firat University, Elazig, Turkey. His research interests include artificial intelligence in education, web-based distance learning, virtual laboratory, remote access laboratory, development and evaluation of educational software.

\section{Ahmet TEKIN}

Departmen of Computer Education and Instructional Technology, Faculty of Education Address: Firat University, 23119, Elazig, Turkey

Phone: +905355441688

E-mail: atekin@firat.edu.tr

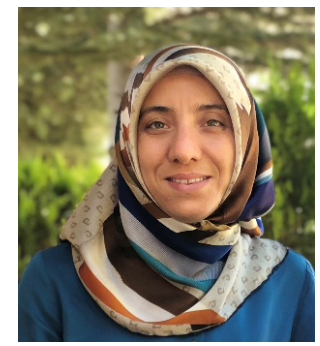

Ebru POLAT is a teacher at Elazig Science and Art Center, MEB. Her academic interest areas are e-content development, technology integration into education, instructional technologies, and educational data mining. She has journal articles published in international indexes. Also, she has other national and international articles and papers submitted to international meetings.

Ebru POLAT

Elazig Science and Art Center, MEB

Address: Elazig Science and Art Center, Elazig, Turkey

Phone: +90 5304909212

E-mail: ebruspolat@gmail.com.tr 


\section{REFERENCES}

Agamba, J. J., \& Keengwe, J. (2012). Pre-Service Teachers' Perceptions of Information Assurance and Cyber Security. International Journal of Information and Communication Technology Education (IJICTE), 8 (2), 94-101.

Akcil, U., Altinay, Z., \& Altinay, F. (2016). Assessing the Effects of Managers in the Digital Age on the Management Process of Digital Citizenship Roles. ANTHROPOLOGIST, 23 (1-2), 209-217.

Akgun, O. E., \& Topal, M. (2015). Egitim fakultesi son sinif ogrencilerinin bilisim guvenligi farkindaliklari: sakarya universitesi egitim fakultesi ornegi. [Information Security Awareness of the Senior Teacher Students: Sakarya University Sample] Sakarya University Journal of Education, 5(2), 98-121.

Alqahtani, A., Alqahtani, F., \& Alqurashi, M. (2017). The Extent of Comprehension and Knowledge with Respect to Digital Citizenship Among Middle Eastern and US students at UNC. Journal of Education and Practice, 8 (9), 96-102.

Al-Zahrani, A. (2015). Toward digital citizenship: Examining factors affecting participation and involvement in the Internet society among higher education students. International Education Studies, 8(12), 203.

Aslan, S. (2016). Ilkogretim Sosyal Bilgiler Ogretmen Adaylarinin Vatandaslik Duzeylerinin Incelenmesi (Firat, Dicle, Siirt, Adiyaman Universiteleri Ornegi). Yayimlanmamis Yuksek Lisans Tezi. Firat Universitesi Egitim Bilimleri Enstitusu. Elazig

Bakir, E. (2016). Sinif Ogretmeni Adaylarinin Dijital Vatandaslik Seviyelerinin Dijital Vatandaslik Alt Boyutlarina Gore Incelenmesi. Yayimlanmamis Yuksek Lisans Tezi. Karadeniz Teknik Universitesi Egitim Bilimleri Enstitusu: Trabzon.

Berson, M. J., \& Balyta, P. (2004). Technological thinking and practice in the social studies: Transcending the tumultuous adolescence of reform. Journal of Computing in Teacher Education, 20(4), 141-150.

Beycioglu, K. (Ed.). (2012). Ethical Technology Use, Policy, and Reactions in Educational Settings. IGI Global.

Blackwell, C. K., Lauricella, A. R., Wartella, E., Robb, M., \& Schomburg, R. (2013). Adoption and use of technology in early education: The interplay of extrinsic barriers and teacher attitudes. Computers \& Education, 69, 310-319.

Bolick, C. M., Berson, M., Coutts, C., \& Heinecke, W. (2003). Technology applications in social studies teacher education: A survey of social studies methods faculty. Contemporary issues in technology and teacher education, 3(3), 300-309.

Buyukozturk, S., Kilic Cakmak, E., Akgun, O. E., Karadeniz, S., \& Demirel, F. (2015). Bilimsel arastirma yontemleri. [Scientific research methods]. Ankara.

Choi, M. (2016). A concept analysis of digital citizenship for democratic citizenship education in the internet age. Theory \& research in social education, 44(4), 565-607.

Choi, M., Glassman, M., \& Cristol, D. (2017). What it means to be a citizen in the internet age: Development of a reliable and valid digital citizenship scale. Computers \& Education, 107, 100-112.

Covell, K., Howe, R. B., \& McNeil, J. K. (2010). Implementing children's human rights education in schools. Improving Schools, 13(2), 117-132.

Cubukcu, A., \& Bayzan, S. (2013). Turkiye'de dijital vatandaslik algisi ve bu algiyi internetin bilincli, guvenli ve etkin kullanimi ile artirma yontemleri. Middle Eastern \& African Journal of Educational Research, $5,148-174$.

Ernest, J. M., Causey, C., Newton, A. B., Sharkins, K., Summerlin, J., \& Albaiz, N. (2014). Extending the global dialogue about media, technology, screen time, and young children. Childhood Education, 90(3), 182-191.

Gokmen, O. F., \& Akgun, O. E. (2015). Bilgisayar ve ogretim teknolojileri egitimi ogretmen adaylarinin bilisim guvenligi egitimi verebilmeye yonelik yeterlilik algilarinin incelenmesi. Ilkogretim Online, 14(4). 
Gokmen, O. F., \& Akgun, O. E. (2016). Ogretmen Adaylarinin Bilisim Suclarina Yonelik Deneyimleri ve Bilisim Guvenligi Ders Icerigine Yonelik Gorusleri/Teacher Candidates' Experiences of Cyber Crime and Their Views for the Information Security Course Content. Mustafa Kemal Universitesi Sosyal Bilimler Enstitusu Dergisi, 13(33).

Gormez, E. (2016). Ogretmen Adaylarinin” Dijital Vatandaslik Ve Alt Boyutlari” Hakkindaki Gorusleri (Bir Durum Calismasi). Electronic Turkish Studies, 11(21).

Greenhow, C., \& Robelia, B. (2009). Informal learning and identity formation in online social networks. Learning, Media and Technology, 34(2), 119-140.

Hatzigianni, M., \& Margetts, K. (2012). 'I am very good at computers': young children's computer use and their computer self-esteem. European Early Childhood Education Research Journal, 20(1), 3-20.

Hermes, J. (2006). Citizenship in the age of the internet. European Journal of Communication, 21(3), 295-309.

Hill, V. (2015). Digital citizenship through game design in Minecraft. New Library World, 116(7/8), 369-382.

Hollandsworth, R., Dowdy, L., \& Donovan, J. (2011). Digital citizenship in K-12: It takes a village. TechTrends, 55(4), 37-47.

Hollandsworth, R., Donovan, J., \& Welch, M. (2017). Digital citizenship: You can't go home again. TechTrends, 61(6), 524-530.

Instefjord, E., \& Munthe, E. (2016). Preparing pre-service teachers to integrate technology: an analysis of the emphasis on digital competence in teacher education curricula. European Journal of Teacher Education, 39(1), 77-93.

Isman, A., \& Canan Gungoren, O. (2013). Being digital citizen. Procedia-Social and Behavioral Sciences, $106,551-556$.

Isman, A., \& Canan Gungoren, O. (2014). Digital citizenship. TOJET: The Turkish Online Journal of Educational Technology, 13(1).

ISTE (International Society for Technology in Education). (2014). ISTE Standards for students. https:// www.iste.org/standards/for-students (Date of access: 10.12.2017)

Ivanoff, K. \& Belvery, J. (2016). "Digital Security”. DigitalCitizenship. N.P.,n.d.

Janisse, H. C., Li, X., Bhavnagri, N. P., Esposito, C., \& Stanton, B. (2017). A Longitudinal Study of the Effect of Computers on the Cognitive Development of Low-Income African American Preschool Children. Early Education and Development, 1-16.

Jones, L. M., \& Mitchell, K. J. (2016). Defining and measuring youth digital citizenship. New media \& society, 18(9), 2063-2079.

Karaduman, H. (2017). Social Studies Teacher Candidates' Opinions about Digital Citizenship and Its Place in Social Studies Teacher Training Program: A Comparison between the USA and Turkey. Turkish Online Journal of Educational Technology-TOJET, 16(2), 93-106.

Karaduman, H., \& Ozturk, C. (2014). Sosyal Bilgiler Dersinde Dijital Vatandasliga Dayali Etkinliklerin Ogrencilerin Dijital Vatandaslik Tutumlarina Etkisi ve Dijital Vatandaslik Anlayislarina Yansimalari. Journal of Social Studies Education Research, 5(1).

Kaya, A., \& Kaya, B. (2014). Teacher candidates' perceptions of digital citizenship Ogretmen adaylarinin dijital vatandaslik algisi. Journal of Human Sciences, 11(2), 346-361.

Kim, W., Jeong, O.-R., Kim, C., \& So, J. $(2011,5)$. The dark side of the Internet: Attacks, costs and responses. Information Systems, 675-705

Kocadag, T. (2012). Ogretmen Adaylarinin Dijital Vatandaslik Duzeylerinin Belirlenmesi. Yayimlanmamis Yuksek Lisans Tezi. Karadeniz Teknik Universitesi Egitim Bilimleri Enstitusu: Trabzon.

Lenhart, A., Madden, M., Smith, A., Purcell, K., Zickuhr, K., \& Rainie, L. (2011). Teens, Kindness and Cruelty on Social Network Sites: How American Teens Navigate the New World of" Digital Citizenship". Pew Internet \& American Life Project. 
Liu, Q., Safavi-Naini, R., \& Sheppard, N. P. (2003). Digital rights management for content distribution. In Proceedings of the Australasian information security workshop conference on ACSW frontiers 2003-Volume 21 (pp. 49-58). Australian Computer Society, Inc..

Livingstone, S., Haddon, L., Gorzig, A., \& Ólafsson, K. (2011). Risks and safety on the internet: the perspective of European children: full findings and policy implications from the EU Kids Online survey of 9-16 year olds and their parents in 25 countries. EU Kids Online, Deliverable D4. EU Kids Online Network, London, UK.

McCarrick, K., \& Li, X. (2007). Buried treasure: The impact of computer use on young children's social, cognitive, language development and motivation. AACE Journal, 15(1), 73-95.

McManis, L. D., \& Gunnewig, S. B. (2012). Finding the education in educational technology with early learners. YC Young Children, 67(3), 14.

Moreillon, J. (2013). Leadership: teaching digital citizenship. School Library Monthly, Vol. 30 No. 1, pp. $26-27$.

Mossberger, K., Tolbert, C. J., \& Anderson, C. (2014). Digital citizenship: Broadband, mobile use, and activities online. In International Political Science Association conference, Montreal.

Mossberger, K., Tolbert, C. J., \& McNeal, R. S. (2008). Digital citizenship: The Internet, society, and participation. MIt Press.

Nikolopoulou, K. (2014). ICT integration in preschool classes: Examples of practices in greece. Creative Education, 5(6), 402-410.

Ohme, J. (2018). Updating citizenship? The effects of digital media use on citizenship understanding and political participation. Information, Communication \& Society, 1-26.

O'Neill, B. (2013). Online child protection and empowerment in a global context. The Routledge International Handbook of Children, Adolescents, and Media, 395.

OECD (2012). https://www.oecd.org/sti/ieconomy/childrenonline_with_cover.pdf (Date of access: January 2018)

Ohler, J. (2012). Digital citizenship means character education for the digital age. Kappa Delta Pi Record, 47(sup1), 25-27.

Palaiologou, I. (2016). Children under five and digital technologies: implications for early years pedagogy. European Early Childhood Education Research Journal, 24(1), 5-24.

Parette, H. P., Quesenberry, A. C., \& Blum, C. (2010). Missing the boat with technology usage in early childhood settings: A 21st century view of developmentally appropriate practice. Early Childhood Education Journal, 37(5), 335-343.

Park, Y. (2016). An Innovative Digital Citizenship Initiative in Singapore and Korea. In SITE: Society for Information Technology \& Teacher Education International Conference. Society for Information Technology \& Teacher Education.

Pusey, P., \& Sadera, W. A. (2011). Cyberethics, cybersafety, and cybersecurity: Preservice teacher knowledge, preparedness, and the need for teacher education to make a difference. Journal of Digital Learning in Teacher Education, 28(2), 82-85.

Ribble, M. (2011). Digital citizenship in schools. International Society for Technology in Education, Oregon.

Ribble, M. (2012). Digital citizenship for educational change. Kappa Delta Pi Record, 48(4), 148-151.

Ribble, M. S. \& Bailey, G. D. (2005). Teaching digital citizenship: when will it become a priority for 21st century schools. School Business Affairs, 71(3), 11-14.

Ribble, M. S., Bailey, G. D., \& Ross, T. W. (2004). Digital citizenship: Addressing appropriate technology behavior. Learning \& Leading with technology, 32(1), 6.

Ribble, M., \& Miller, T. N. (2013). Educational Leadership in an Online World: Connecting Students to Technology Responsibly, Safely, and Ethically. Journal of asynchronous learning networks, 17(1), 137-145. 
Rideout, V. J., Foehr, U. G., \& Roberts, D. F. (2011). Generation M2: Media in the Lives of 8 to 18 year Olds. Henry J. Kaiser Family Foundation.

Sakalli, H. (2015). Sinifogretmeni adaylarinin dijital vatandaslik duzeyleri ile siber zorbalik egilimleri arasindaki iliskinin incelenmesi . Yayimlanmamis Yuksek Lisans Tezi. Adnan Menderes Universitesi, Sosyal Bilimler Enstitusu, Aydin.

Sakalli, H., \& Ciftci, S. (2016). Sinif Ogretmeni Adaylarinin Dijital Vatandaslik Duzeyleri Ile Siber Zorbalik Egilimleri Arasindaki Iliskinin Incelenmesi. Egitim Teknolojisi Kuram ve Uygulama, 6(2).

Schlichter, B. R., \& Danylchenko, L. (2014). Measuring ICT usage quality for information society building. Government Information Quarterly, 31(1), 170-184.

Searson, M., Hancock, M., Soheil, N., \& Shepherd, G. (2015). Digital citizenship within global contexts. Education and Information Technologies, 20(4), 729.

Sincar, M. (2011). An analysis of prospective teachers' digital citizenship behaviour norms. International Journal of Cyber Ethics in Education (IJCEE), 1(2), 25-40.

Siemens, G. (2005). Connectivism: A learning theory for the digital age. International Journal of Instructional Technology and Distance Learning, 2(1) http://www.itdl.org/JournallJan_05/article01.htm

Sullivan, A., \& Bers, M. U. (2016). Robotics in the early childhood classroom: learning outcomes from an 8-week robotics curriculum in pre-kindergarten through second grade. International Journal of Technology and Design Education, 26(1), 3-20.

Tan, T. (2011). Educating digital citizens. Leadership, 41(1), 30-32.

Tekin, A., Polat, E. (2016). Ortaokul Ogrenci Velilerinin Guvenli Internet Kullanimi Farkindaligi [Secondary School Students' Parents' Safe Internet Usage Awareness]. Journal of Instructional Technologies \& Teacher Education, 5(2).

Third, A., Bellerose, D., Dawkins, U., Keltie, E., \& Pihl, K. (2014). Children's Rights in the Digital Age: A Download from Children Around the World. Abbotsford, Vic.: Young and Well Cooperative Research Centre. Retrieved from http://researchdirect.westernsydney.edu.au/islandora/object/ uws\%3A28202/datastream/PDF/download/citation.pdf

Weigel, M., James, C., \& Gardner, H. (2009). Learning: Peering backward and looking forward in the digital era. International Journal of Learning and Media. (1)1.(1-18).

Yang, H. H., \& Chen, P. (2010). Exploring teachers' beliefs about digital citizenship and responsibility. Technological Developments in Networking, Education and Automation, 49-54.

Yilmaz, E., Sahin, Y. L., \& Akbulut, Y. (2015). Dijital Veri Guvenligi Farkindaligi Olceginin Gelistirilmesi. AJIT-e: Online Academic Journal of Information Technology, 6(21).

YOK (Yuksek Ogretim Kurumu). Egitim Fakultesi Ogretmen Yetistirme Lisans Programlari. http://www. yok.gov.tr/web/guest/icerik/-/journal_content/56_INSTANCE_rEHF8BIsfYRx/10279/49875. (Data of Access: 08.01.2018)

York, L. (2014). Preservice Teachers: What do They Know about Cyberlaw? In SITE International Symposium: Future Focussed Teacher Education. Society for Information Technology \& Teacher Education.

Yue, A., Nekmat, E., \& Beta, A. R. (2019). Digital literacy through digital citizenship: Online civic participation and public opinion evaluation of youth minorities in Southeast Asia. Media and Communication, 7(2), 100-114.

Xu, S., Yang, H. H., MacLeod, J., \& Zhu, S. (2019). Social media competence and digital citizenship among college students. Convergence, 25(4), 735-752.

Zeybek, G. (2011). Bilgisayar meslek dersi alan ortaogretim ogrencilerinin bilisim teknolojilerini kullanimlarinin etik acidan degerlendirilmesi. Yuksek Lisans Tezi.Selcuk Universitesi Egitim Bilimleri Enstitusu. 